\title{
In closing a surface waste rock dump it is not simply a matter of constructing a cover retrospectively
}

\author{
D.J. Williams School of Civil Engineering, The University of Queensland, Australia
}

\begin{abstract}
Surface waste rock dumps may not appear to generate acid and metalliferous drainage from the start of their construction. However, the scene is set for potentially contaminated seepage as soon as the first reactive waste rock is placed. Once reactive waste rock is exposed to oxygen, oxidation reactions commence. The placement of this material in a surface waste rock dump also exposes it to rainfall infiltration from the surface and to wetting up from the base by runoff along buried surface channels beneath the dump. Rainfall infiltration into an uncovered dump is likely to be of the order of $50 \%$ of cumulative rainfall, depending on the compaction of the top surface, the climate and the age of the dump. Initially, most of the rainfall infiltration and runoff will go into storage within the dumped waste rock, with little or none seeping into the foundation or emerging as toe seepage at topographic low points around the dump. The dump will gradually wet up over time, as a function of the climatic conditions, the rate of construction of the dump and the height it achieves, and the nature of the waste rock dump and how it breaks down with time. The wetter the climate, the more rapidly will the dump wet up. The faster the dump is constructed and the greater its' final height, the longer it will take for seepage to break through. The finer-grained the waste rock and/or the quicker it breaks down, the more water it will store and the more saturated it will need to become before base seepage will emerge.
\end{abstract}

Typically, a waste rock dump is left open to oxygen ingress and rainfall infiltration during its operational life. This may be of the order of 20 years. During this time, it is most likely that some base seepage will emerge, associated with high rainfall events. The older the dump, the more likely is base seepage to emerge, the lower the trigger rainfall required to initiate seepage, and the shorter the lag between rainfall and seepage. If the dump is left open to oxygen ingress and rainfall infiltration for say 20 years, and even if an impermeable cover could be placed at that time, the water stored in the dump will drain down over a period of a further 20 years or more. Just as wetting up will increase exponentially with time to a degree of saturation at which drain down will occur, drain down will decrease exponentially with time to a rate that matches the infiltration rate. In reality, an impermeable cover will not be possible, and the drain down will eventually reach the net percolation rate through any cover.

The paper provides guidelines on the selective placement and encapsulation of reactive waste rock, with a benign or alkaline base layer, wide side encapsulation by benign or alkaline waste rock, the exclusion of reactive waste rock from beneath side slopes, and a benign or alkaline low net percolation top cover. Drawing on the approach of progressive covering of landfills as they are built, the paper recommends means of progressively covering each lift of the dump as it is constructed, to limit oxygen ingress and wetting up, and hence limit potential acid and metalliferous drainage.

\section{Introduction}

Many ore bodies that extend below the groundwater table are surrounded by waste rock that contains sulphides, often in the form of pyrite $\left(\mathrm{FeS}_{2}\right)$. Surface waste rock dumps containing loose-dumped, potentially acid forming (PAF) sulphidic waste rock are essentially 'oxidation reactors', since they have a ready supply of oxygen, and are a 'sponge' for rainfall infiltration that collects and flushes oxidation products, leading the generation of acid and metalliferous drainage (AMD). 
Rainfall infiltration into an uncovered surface waste rock dump will be high. However, it will initially go largely into storage within the dumped waste rock. Hence, there is generally a time-lag of several years before the emergence of seepage and any AMD from low points around the toe of a surface waste rock dump. This is a function of the cumulative rainfall infiltration and rate, the height of the dump, the particle size distribution of the waste rock and how this changes as it breaks down over time, the hydraulic conductivity of the foundation beneath the dump, and the topography of the natural surface beneath the dump.

The greater the storm magnitude, the greater the rainfall intensity, and the more pervious the surface of the dump, the greater will be the infiltration into the dump. The higher the dump, and the more quickly it is constructed to that height, the longer it will take for the dump to wet up due to rainfall infiltration. The finer the particle size distribution of the waste rock, and the more prone it is to physical and chemical breakdown, the more it will need to wet up before base seepage will emerge. The higher the hydraulic conductivity of the foundation beneath the dump, the greater will be the infiltration into the foundation, and the longer the delay before the emergence of seepage from the toe of the dump. The lower the hydraulic conductivity of the foundation, the sooner seepage and any AMD will emerge from the toe of the dump. The more pronounced the topography of the natural surface beneath the dump, the more base seepage will concentrate in buried channels and emerge from topographic low points around the toe of the dump.

The paper discusses natural recharge rates and excess rainfall conditions, before describing the conventional construction and wetting-up of surface waste rock dumps, and the likely time-lags involved before the emergence of base and toe seepage. Means of selectively placing and encapsulating PAF waste rock to limit its exposure to oxygen and rainfall infiltration, and means of progressively covering each lift of the dump as it is constructed to further limit oxygen ingress and wetting up, and so limit AMD, are then discussed.

\section{Natural recharge rates and excess rainfall conditions}

In arid and semi-arid regions, where many of the world's mines are located, the groundwater is deep and is overlain by an unsaturated zone of very low hydraulic conductivity. Streams are predominantly ephemeral, often underlain by a perched underground stream in a sand or gravel bed, which itself is underlain by an unsaturated zone above the groundwater table. The base of the underground stream is effectively 'sealed' by fine sediments and regoliths, delivering limited water to the unsaturated zone beneath and maintaining its unsaturated state and very low hydraulic conductivity. If this were not the case, all surface and nearsurface water would rapidly disappear to the ground, which has ample porosity to store it. There may be a number of perched water tables or aquifers in the profile and in tight rock groundwater may be restricted to fracture zones.

\subsection{Natural recharge rates}

Groundwater recharge data reported by Beekmann et al. (1996) for arid and semi-arid Southern Africa highlight the effect of climate on recharge rates, as reproduced in Figure 1. Groundwater recharge in arid and semi-arid areas of Australia still covered by the original native vegetation is close to zero (Cook et al., 2004), since native vegetation has evolved to be particularly efficient at removing the limited available moisture, remaining dormant during droughts and blooming following wet periods. Much of the recharge of the Great Artesian Basin, which covers more than $20 \%$ of northeastern Australia, is via outcropping sandstone along the western slopes of the Great Dividing Range, with contributions via leakage from streams and rainfall infiltration (Cox and McKay, 2003). For the average annual rainfall for Australia as a whole of $600 \mathrm{~mm}$, Figure 1 implies an average annual natural recharge of about $70 \mathrm{~mm}$ (12\% of average annual rainfall, c.f. the typical $50 \%$ of average annual rainfall for an uncovered waste rock dump). This corresponds to an equivalent hydraulic conductivity of about $2 \times 10^{-9} \mathrm{~m} / \mathrm{s}$. 
Stripping or burning native vegetation for grazing purposes, which covers about $60 \%$ of Australia's land area, is likely to increase recharge rates to between about $1 \mathrm{~mm} /$ year and $10 \mathrm{~mm} /$ year. Irrigation for cropping, which covers about $6 \%$ of Australia's land area, is likely to increase recharge rates to between about $10 \mathrm{~mm} /$ year and $100 \mathrm{~mm} /$ year, with infiltration rates increasing as continued irrigation wets up the unsaturated zone, rendering it more permeable (Cox and McKay, 2003).

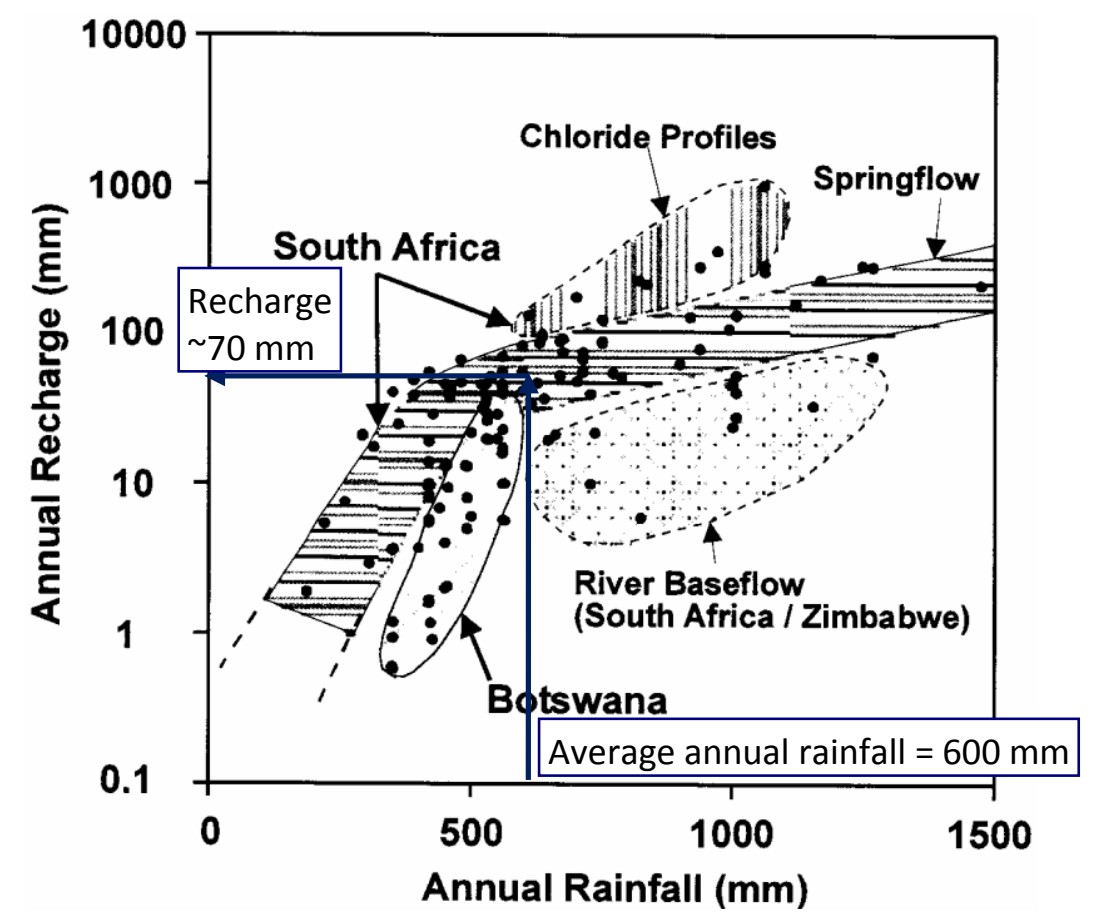

Figure 1 Results of recharge studies from Southern Africa (after Beekmann et al., 1996)

\subsection{Rainfall versus actual evapotranspiration}

Based on the Australian Bureau of Meteorology (BOM, www.bom.gov.au) and worldwide climatic data (www.blueplanetbiomes.org/climate.htm and www.worldweather.org) for a range of major mine sites worldwide, the average annual rainfall and actual evapotranspiration have been compared in Figure 2 (after Williams, 2008). Figure 2 shows a threshold average annual rainfall of about $250 \mathrm{~mm} /$ year (corresponding to the average annual rainfall of Kalgoorlie in Western Australia), above which net infiltration would be expected and below which net evapotranspiration would be expected. 


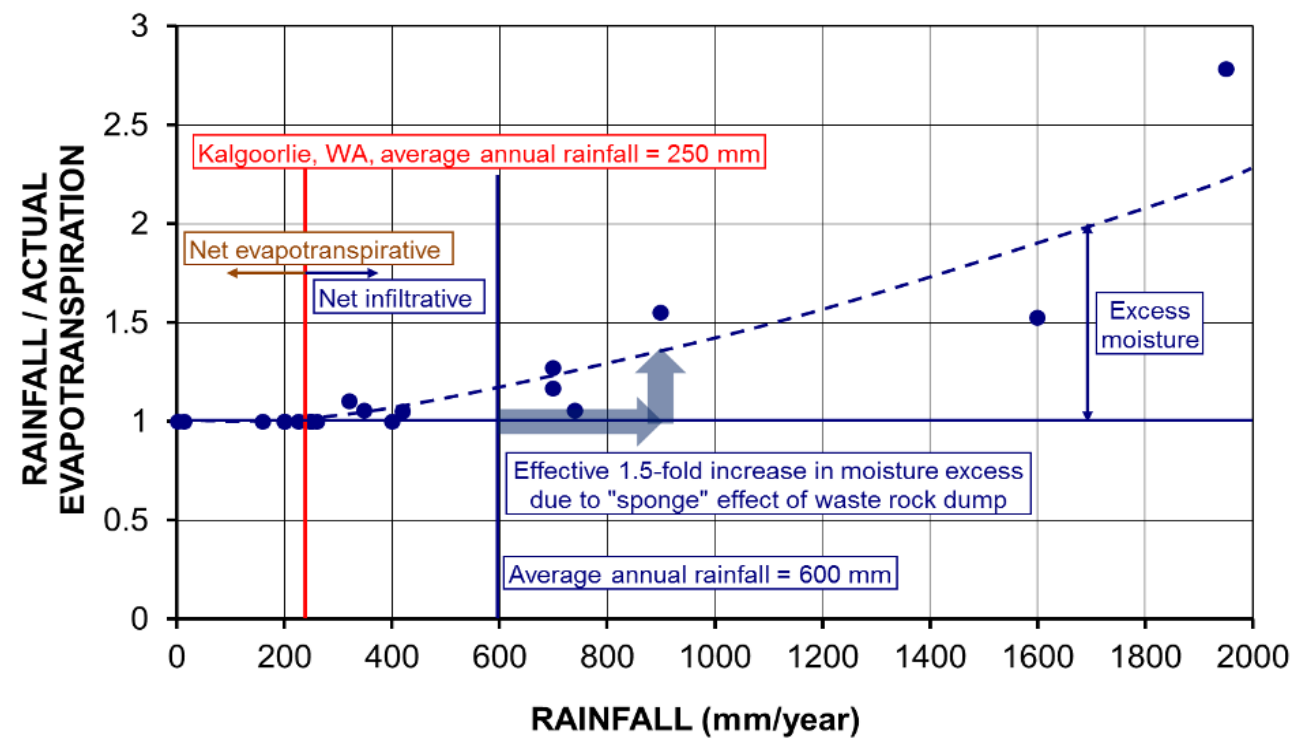

\section{Figure 2 Rainfall/actual evapotranspiration versus rainfall}

Extreme rainfall events would induce some net infiltration even for arid sites, and the relatively pervious nature of waste rock dumps compared with natural ground would increase this. For the typical infiltration of $50 \%$ of rainfall into the top of an uncovered surface waste rock dump (Williams, 2008), and for the average annual rainfall for Australia of $600 \mathrm{~mm}$, a waste rock dump generates an effective 1.5 fold increase in excess moisture, as shown in Figure 2.

\section{Conventional surface waste rock dumps}

Surface waste rock dumps are conventionally constructed by end-dumping from haul trucks from a series of tip-heads to create a series of lifts with a vertical height of typically about $15 \mathrm{~m}$ (see Figures 3 and 4). By maintaining the benches between lifts as haul roads, the dump may be extended in any direction and at any elevation.
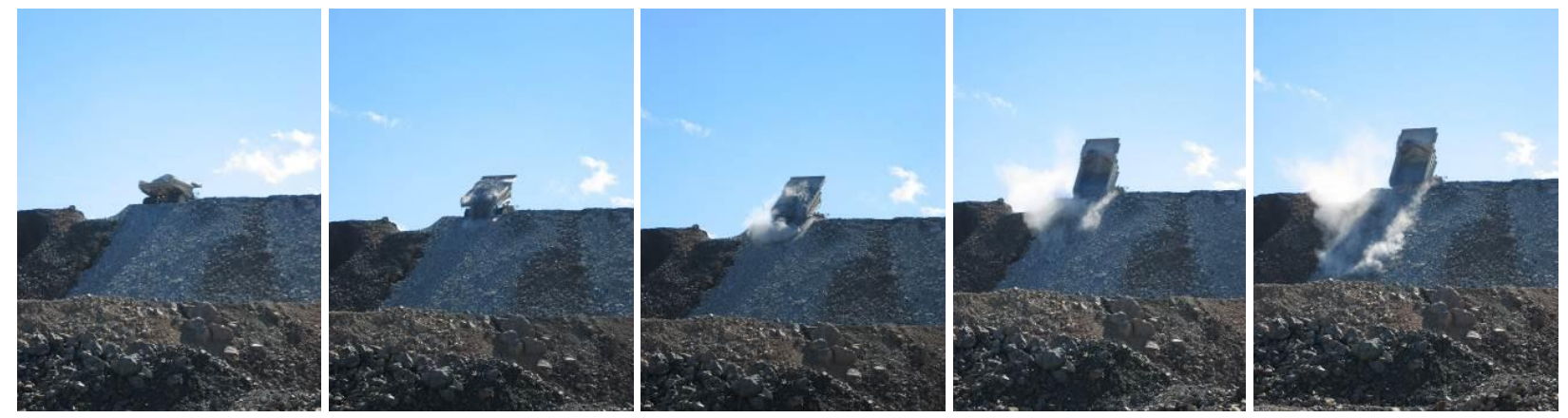

Figure 3 Sequence of end-dumping off a surface waste rock dump tip-head
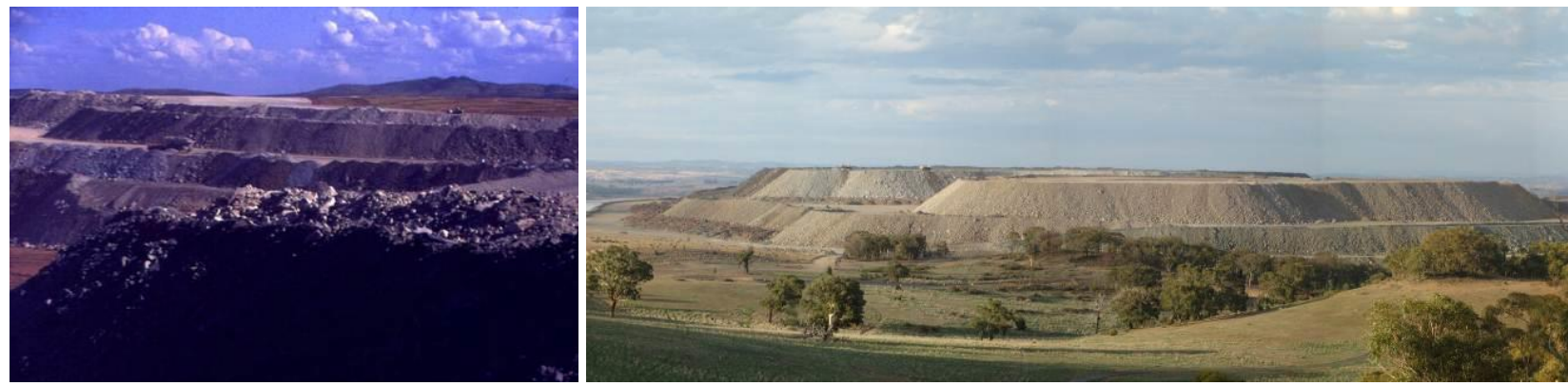

Figure 4 Series of tip-heads creating series of lifts of surface waste rock dumps 
End-dumping, whether over a natural rock slope or a waste rock slope, creates a continuous base rubble zone (see Figure 5), and discontinuous, alternating angle of repose layers of fine and coarse-grained waste rock between the base rubble zone and the horizontally-bedded trafficked surface layer (see Figure 6).

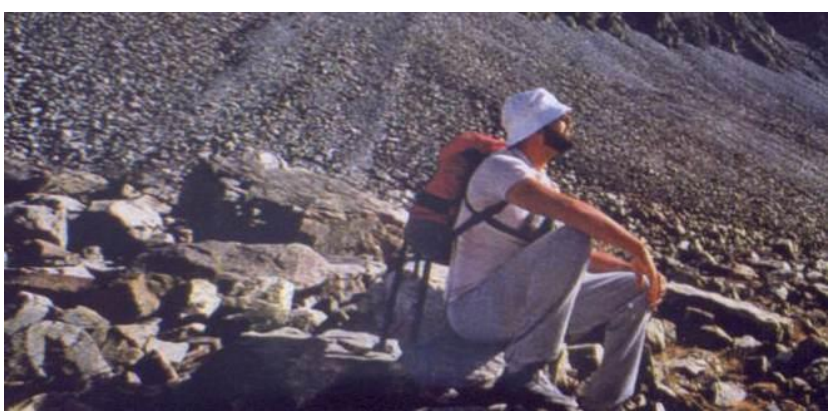

(a)

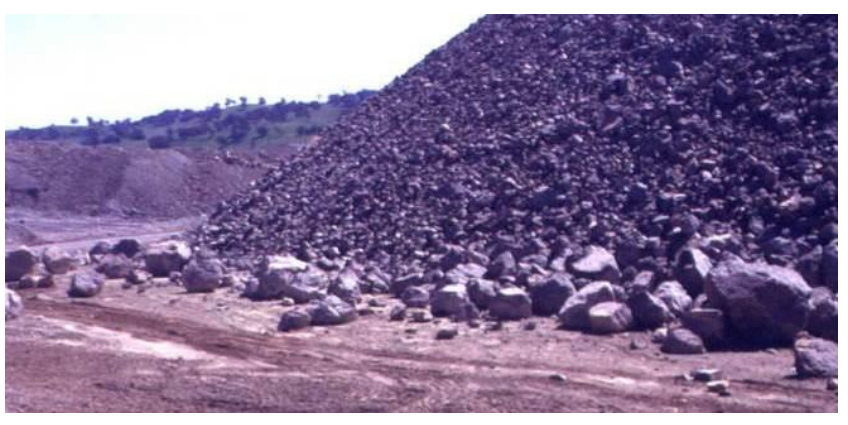

(b)

Figure 5 Formation of base rubble zone of a surface waste rock dump: (a) Natural rock slope, and (b) Waste rock dump slope

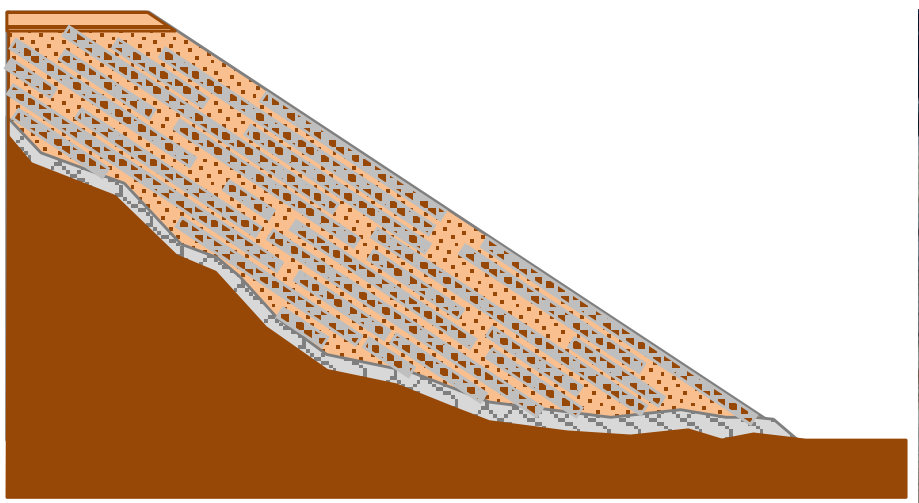

(a)

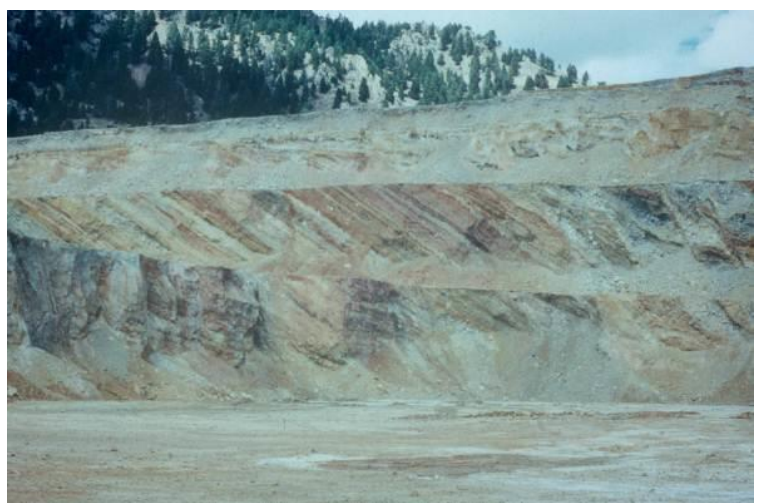

(b)

Figure 6 Structure of waste rock dump formed by end-dumping: (a) Schematic showing base rubble zone, trafficked surface layer and discontinuous, alternating fine and coarse-grained layers between, and (b) Section through dump showing trafficked layers and discontinuous, alternating fine and coarse-grained layers within each lift (after G.W. Wilson, 2003, pers. comm.)

The base rubble zone that inevitably forms due to the ravelling of coarse-particles to the toe of the dump on end-dumping delivers oxygen to the coarse-grained angle of repose layers above, which then diffuses into the adjacent fine-grained layers that present a high reactive surface area. There will also be some ingress of oxygen into the sides of the dump and a minor amount of diffusion of oxygen through the trafficked surfaces of the dump.

Each lift is typically extended over the entire footprint of the dump, and the entire footprint is left exposed to oxygen ingress and rainfall infiltration for the life of the dump. On closure, the top surface of the dump is typically covered with relatively fine-grained non-acid forming (NAF) material designed to minimise net percolation into the underlying waste rock (including PAF waste rock), while the side slopes of the dump are typically dozed and covered with a growth medium.

\subsection{Physical characterisation of waste rock}

The particle size distribution of waste rock is a function of the degree of weathering and fracturing of the rock in situ, and the blast pattern density and amount of explosives used. Typical particle size distribution curves for weathered waste rock (representative of that excavated following blasting at shallow depth, 
above the groundwater table), and fresh waste rock (representative of that excavated following blasting, from below the groundwater table) are plotted in Figure 7(a), which highlights their distinct differences.

\subsection{Moisture state of waste rock dumps during operation}

In an arid or semi-arid environment, which describes the climate in which many of Australia's mines operate, waste rock emerges from an open pit with a low gravimetric moisture content (mass of water/mass of solids, expressed as a percentage) of typically $2-5 \%$, which equates to a volumetric water content (volume of water/total volume, expressed as a decimal) of 0.035-0.09 (Williams, 2006). The precise moisture content depends on the initial degree of weathering of the waste rock and hence its particle size distribution and moisture retention characteristics, and the climatic season.

From the outset, a surface waste rock dump closes off natural surface evaporation (the amount of pan evaporation being several times that of rainfall in arid and semi-arid climates), while allowing rainfall infiltration. Rainfall infiltration into loosely-dumped, initially relatively dry waste rock in a surface dump initially goes to wetting-up the surfaces of the rock particles and is largely held in storage within the dump. Any flow through the dump is via preferred pathways, with seepage only reaching the base of the dump following intense, heavy rainfall events, and amounting to at most a few percent of rainfall, equivalent to an average hydraulic conductivity of about $6 \times 10^{-10} \mathrm{~m} / \mathrm{s}$ or about $20 \mathrm{~mm} /$ year This early base seepage is a function of the cumulative wetting-up of the dump, which is in turn a function of the cumulative rainfall infiltration into the dump since its construction commenced, the height of the dump, and the particle size distribution of the waste rock.

As the cumulative rainfall increases, the size of rainfall event required to generate some base seepage reduces and the time-lag before base seepage occurs decreases. For the $15 \mathrm{~m}$ high, instrumented waste rock dump constructed at Cadia Hill Gold Mine in New South Wales, Australia, the size of rainfall event required to generate measurable base seepage decreased from $30 \mathrm{~mm}$ initially to $3 \mathrm{~mm}$ after $750 \mathrm{~mm}$ of cumulative rainfall, and the time-lag reduced from about 12 days (equivalent to a local hydraulic conductivity of about $1.4 \times 10^{-5} \mathrm{~m} / \mathrm{s}$ ) initially to about 3 days (equivalent to a local hydraulic conductivity of about $5.8 \times 10^{-5} \mathrm{~m} / \mathrm{s}$; Williams and Rohde, 2008).

Eventually the dump wets-up sufficiently to overcome the capillary tensions that form at particles contacts, and drain down of the dump commences, known as 'continuum breakthrough'. At continuum breakthrough, the rate of seepage from the base of the waste rock dump will match the rate of rainfall infiltration into the top of the dump, and this occurs at a degree of saturation of the waste rock that depends on its particle size distribution. Weathered waste rock must saturate the void space to a degree of saturation (volume of water/volume of voids, expressed as a percentage) of about $60 \%$ before continuum breakthrough occurs, while fresh waste rock need only saturate the void space to about $25 \%$ to allow continuum breakthrough. At these degrees of saturation, the hydraulic conductivity of the respective waste rock materials rises to the rate of rainfall infiltration and allows breakthrough.

Taking rainfall infiltration to be $50 \%$ of rainfall, for the average annual rainfall for Australia of $600 \mathrm{~mm}$, the rate of rainfall infiltration and hence the hydraulic conductivity of the wet-up waste rock dump would be equivalent to $300 \mathrm{~mm} /$ year or about $10^{-8} \mathrm{~m} / \mathrm{s}$. The rainfall infiltration rate will not be high enough to fully saturate the dump, since the hydraulic conductivity of the waste rock becomes too high to allow further storage. The saturated hydraulic conductivities of weathered and fresh waste rock would be of the order of $10^{-5} \mathrm{~m} / \mathrm{s}$ and $10^{-3} \mathrm{~m} / \mathrm{s}$, respectively, orders of magnitude higher than the rate of rainfall infiltration of about $10^{-8} \mathrm{~m} / \mathrm{s}$. Hence, the waste rock remains unsaturated. The rate of base seepage will increase following rainfall and reduce until the next rainfall event recharges the waste rock and initiates an increase in the base seepage rate.

\subsection{Moisture state of waste rock dumps post-closure}

If a low net percolation cover were constructed over the top of a waste rock dump following closure, the dump would drain down to the rate of net percolation. The store and release cover system developed for 
the tops of the waste rock dumps in the seasonal, dry climate of Kidston Gold Mine in northern Queensland, Australia (Williams et al., 1997), has been shown to limit percolation to $1 \%$ (equivalent to about $7 \mathrm{~mm} /$ year) of average annual rainfall, and perhaps up to $5 \%$ (equivalent to about $35 \mathrm{~mm} /$ year) of unseasonally high annual rainfall totals (Williams et al., 2006). It is expected that the rainfall infiltration stored in the Kidston dumps during their 20 year operational life will continue to drain down for perhaps 20 years after the cover was placed in 2001. The measured seepage rate was observed to be decrease exponentially with time, along with the acidity load. Toe seepage and percolation into the foundation beneath the dumps should eventually approach the rate of net percolation through the cover. Any groundwater mounding beneath the dumps should also drop exponentially with time, eventually returning to its original elevation.

For the side slopes of surface waste rock dumps, no cost-effective and sustainable, low net percolation cover system has been developed. The side slopes of most dumps will remain prone to infiltration during heavy or continuous rainfall, and it is therefore essential that they be constructed of benign waste rock of sufficient thickness to produce clean runoff and seepage.

\subsection{Unsaturated relationships for waste rock}

The concept that unsaturated waste rock has a very low hydraulic conductivity appears at first to be counter-intuitive, since waste rock is free draining when saturated. A useful analogy is to consider a bucket and watering can (P. Scott, 2005, pers. comm.). Imagine a dump of dry, coarse-grained waste rock. If you were to pour a bucket-full of water into it, the water would almost immediately flow through, since the pathways between the rock particles would rapidly fill with water, allowing essentially saturated flow. Alternatively, if you were to sprinkle water from a watering can with a fine nozzle over a wide arc over the dump of rock, the water would be stored within the rock pores or on the rock surfaces, without any flowthrough, displaying unsaturated behaviour.

The relationships that describe the unsaturated behaviour of weathered and fresh waste rock in a surface dump are the soil water characteristic curves (SWCCS) and the hydraulic conductivity functions of the materials. The SWCC is a plot of soil water (conventionally in terms of volumetric water content; but it could also be in terms of degree of saturation, or the gravimetric or mining moisture content) versus soil suction (Fredlund and Rahardjo, 1993). It provides the loci of moisture states of a soil from the saturated to the 'oven-dry' state, at a particular test density. The higher the density, the lower the intercept on the vertical axis of the SWCC. Increasing the density, for example by compaction, will induce drainage.

For relatively coarse-grained waste rock, indicative SWCCs may be estimated from the particle size distribution curves given in Figure $7(\mathrm{a})$, plus the estimated dry density (taken as $1.8 \mathrm{t} / \mathrm{m}^{3}$ ) and the specific gravity of the rock (assumed to be 2.65) using the method outlined in Fredlund et al. (1997) and the library of data contained within the program SoilVision. The resulting SWCCs for weathered and fresh waste rock are shown in Figure 7(b).

On drying from near-saturated conditions at a given density (or porosity), waste rock begins to take air into its voids at the Air-Entry Value (AEV), beyond which it is no longer able to remain saturated. On further drying beyond the AEV, the slope of the SWCC indicates the water storage capacity of the waste rock and the ease with which it may be dewatered. A Residual Suction (RS) and corresponding moisture content is reached, reflecting the driest state the waste rock is likely to achieve. To this point, matric (or capillary) suction and liquid water flow dominate. Beyond this point, osmotic (or solute) suction and vapour flow dominate. 


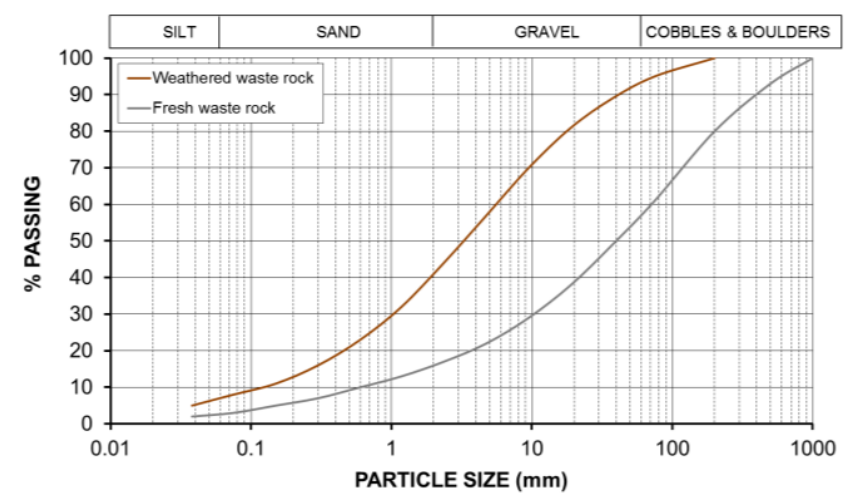

(a)

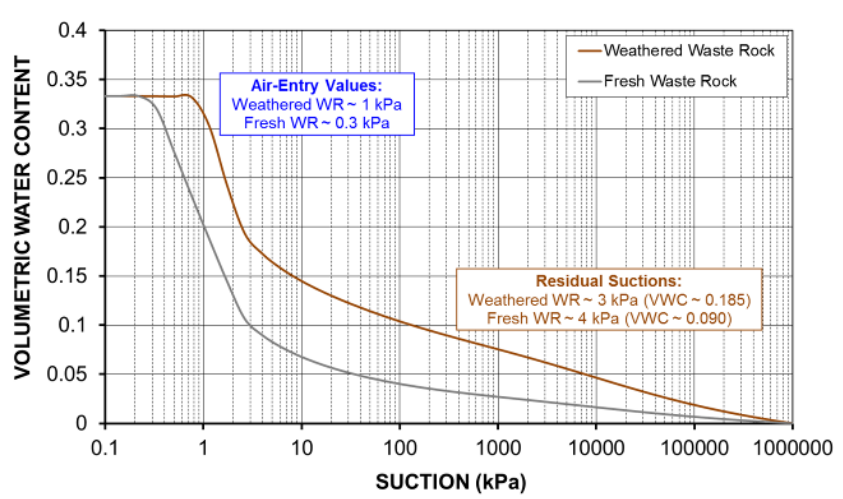

(b)

Figure 7 Physical characterisation of weathered and fresh waste rock: (a) typical particle size distribution curves, and (b) indicative soil water characteristic curves

From the SWCC and measured saturated hydraulic conductivity of the soil, the unsaturated hydraulic conductivity function of the soil may be calculated using the method of Fredlund et al. (1994). The indicative hydraulic conductivity functions for weathered and fresh waste rock are shown in Figure 8 , in terms of suction and volumetric moisture content.

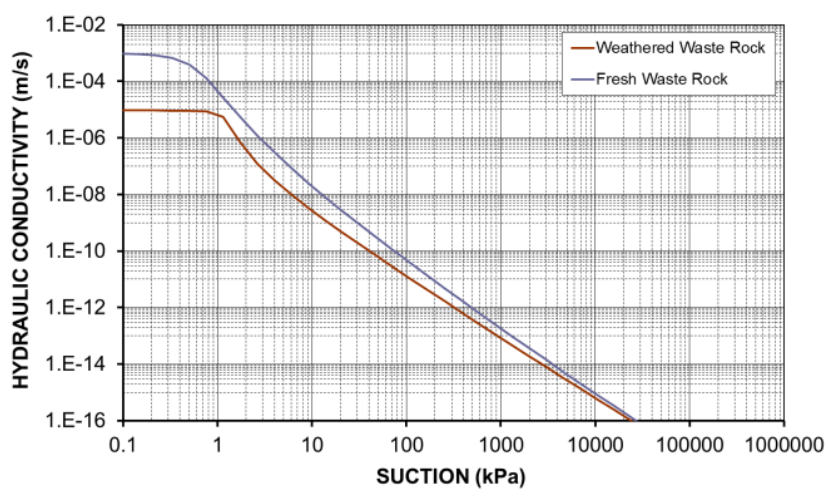

(a)

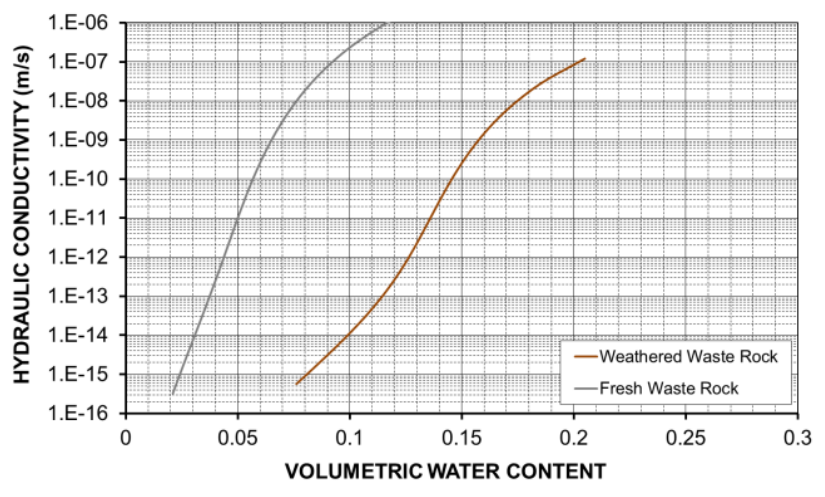

(b)

Figure 8 Indicative hydraulic conductivity functions for weathered and fresh waste rock: (a) in terms of suction, and (b) in terms of volumetric water content

Using the unsaturated hydraulic conductivity functions in terms of volumetric water content (Figure 8(b)), simulations of the wetting-up of surface waste rock dumps comprising weathered or fresh waste rock by rainfall infiltration may be undertaken. Restricting consideration to weathered waste rock only, since experience has shown that even initially fresh waste rock rapidly breaks down in a dump, simulations were carried out in Williams (2007) for uncovered surface waste rock dumps of various heights subjected to various annual rainfalls. The simulations were based on iterative spreadsheet calculations in which the unsaturated hydraulic conductivities of sub-layers of weathered waste rock were updated as they wet-up. Spreadsheet calculations were preferred over numerical methods, which would incur convergence problems due to the high suction gradients within the waste rock as it wets-up. To facilitate the simulations, $50 \%$ of the annual rainfall was assumed to be available to infiltrate (the remainder assumed to be lost to evaporation, since runoff is normally prevented by safety windrows around the perimeter of the dump crest), and infiltration was allowed to occur only during days on which rainfall occurred, assumed to be an average of 40 days/year, or about $10 \%$ of the year. 
Figure 9 shows the estimated years to continuum breakthrough for surface waste rock dumps comprising weathered waste rock. The shading up to 20 years reflects the typical time that a waste rock dump is left uncovered during major mining operations.

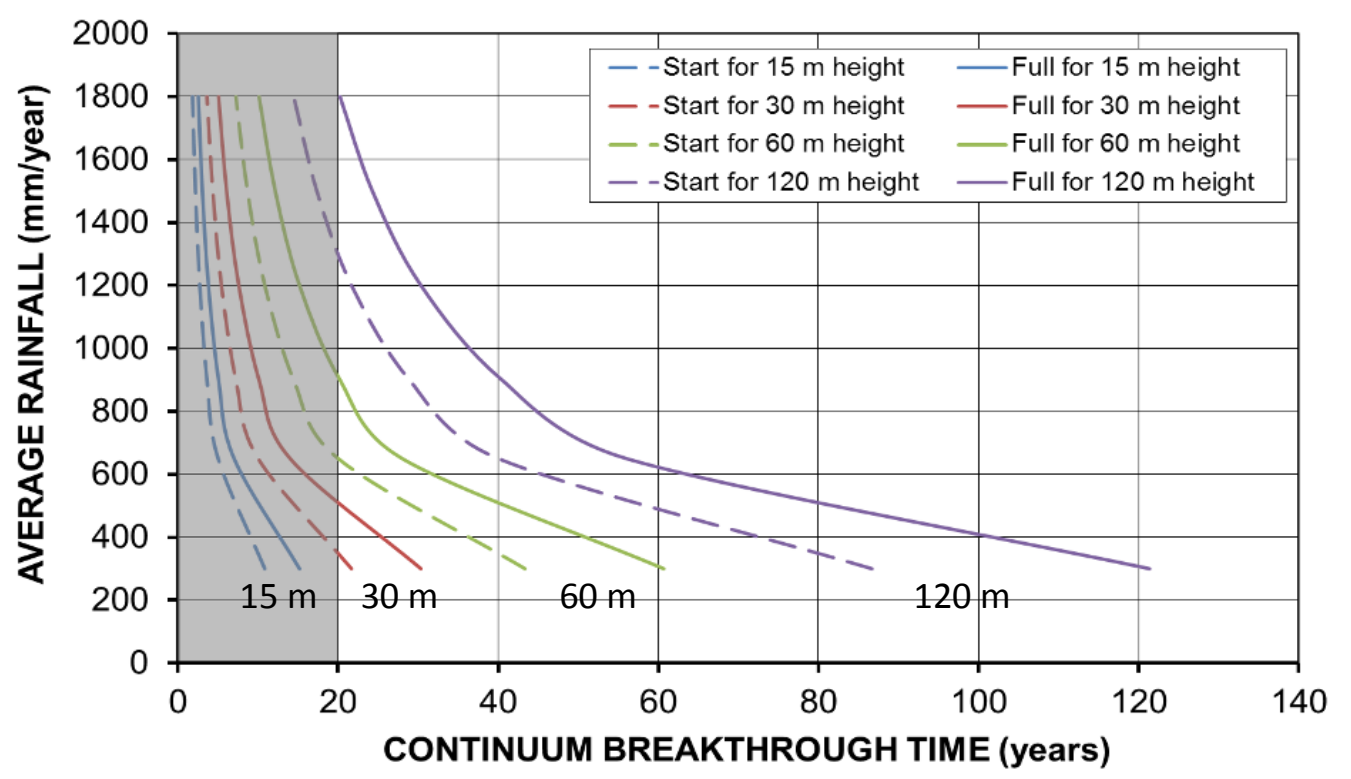

\section{Figure 9 Estimated years to continuum breakthrough for surface waste rock dumps comprising weathered waste rock}

As an example of the application of Figure 9, Kidston's waste rock dumps average about $40 \mathrm{~m}$ high, and were subjected to an average annual rainfall of about $700 \mathrm{~mm}$ for up to about 20 years that they were left uncovered. Hence, they would have been expected to have reached continuum breakthrough. Cadia's instrumented trial waste rock dump was $15 \mathrm{~m}$ high, and was subjected to an average annual rainfall of about $900 \mathrm{~mm}$ over the four year duration of the trial, by which time it would have been expected to be tending towards continuum breakthrough, which the data confirmed (Rohde and Williams, 2009).

Over time, the surface of a waste rock dump may hard pan and self-seal, which will reduce rainfall infiltration and delay or even avoiding continuum breakthrough during operations. Evidence of hard panning or self-sealing is shown in the photographs of the top of the Cadia trial waste rock dump shown in Figure 10, which were taken at the completion of the dump in February 2006, and 18 months later in August 2008. In a very wet climate, a waste rock dump will wet-up and reach continuum breakthrough rapidly, most likely during the life of the mine, and before a low net percolation cover is constructed. 

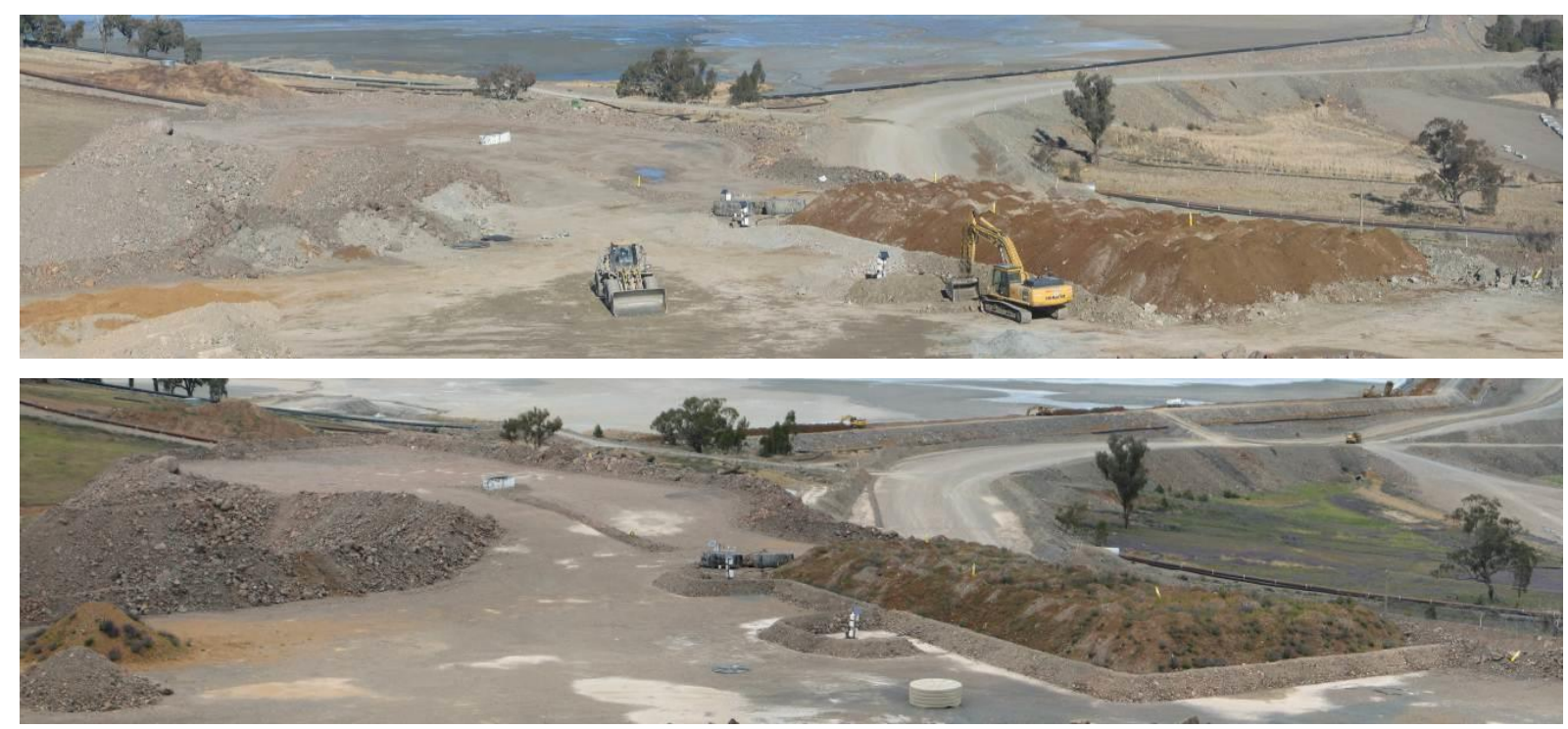

Figure 10 Views of top of Cadia trial waste rock dump; top: at the completion of construction in February 2006; bottom: 18 months later in August 2008

\section{$4 \quad$ Cover systems for waste rock dumps}

Cover systems for the tops of waste rock dumps are intended to limit oxygen ingress and net percolation. The two most common cover types applied to the tops of waste rock dumps are: (a) rainfall-shedding or barrier covers and, (b) store and release covers (Williams et al., 1997, 2006), as shown schematically in Figure 11.

\subsection{Rainfall-shedding covers}

Rainfall-shedding covers were developed for landfills, partly to limit the net percolation of rainfall into the potentially contaminating landfill, but also to accommodate the inevitable large total and differential settlements of the landfill. The key element of a rainfall-shedding cover is a barrier or sealing layer, comprising compacted clayey soil, a geomembrane, or a composite of the two, which is generally overlain by a growth medium. Rainfall-shedding covers are applied in wet climates, in which a vegetative cover can be sustained to limit erosion. 


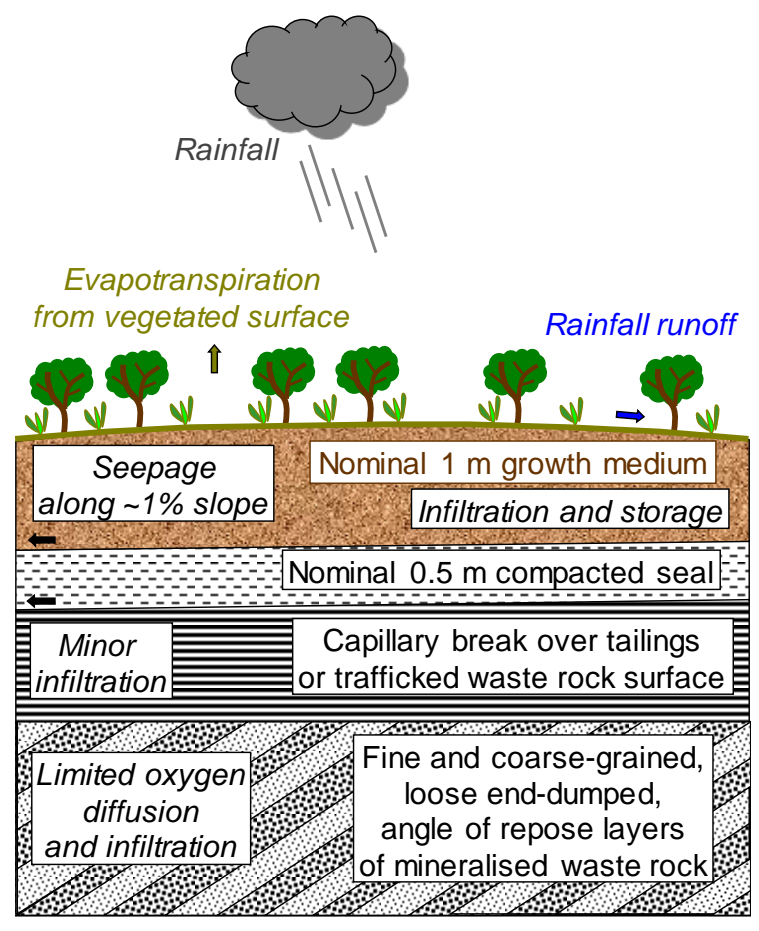

(a)

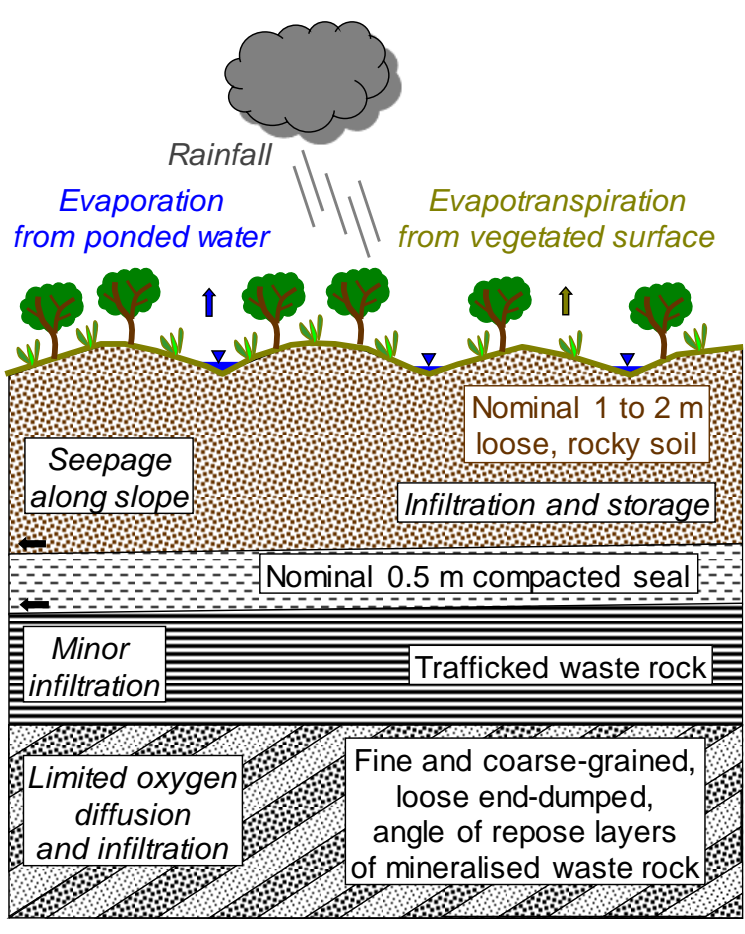

(b)

Figure 11 Most common cover types applied to tops of waste rock dumps: (a) rainfallshedding and, (b) store and release

\subsection{Store and release covers}

The key elements of a store and release cover developed for seasonal, dry climates are: (i) a thick loose rocky soil mulch layer with an undulating surface to store the wet season rainfall without inducing runoff, (ii) an effective sealing layer at the base of the cover to 'hold-up' rainfall infiltration and, (iii) the appropriate choice of sustainable vegetation to release the stored rainfall during the wet season, through evapotranspiration. The required thickness of rocky soil mulch will depend on the wet season rainfall pattern and the rooting depth of the vegetative cover, and is typically about $2 \mathrm{~m}$ thick. This thickness is in fact optimal. Too thin a mulch layer provides too little void space to store the wet season rainfall (a typical porosity of 0.25 provides potential storage for $500 \mathrm{~mm}$ of rainfall infiltration). Too thick a mulch layer will allow the rainfall infiltration to penetrate too deep for plant roots to remove it through evapotranspiration, and it will pond on the sealing layer and promote net percolation into the underlying waste rock. In wet climates in which a $2 \mathrm{~m}$ thick rocky soil mulch layer provides insufficient storage capacity for the wet season rainfall, a drainage layer, perhaps sloped towards the final void, may be included at the base of the mulch layer, above the sealing layer, to handle the excess rainfall infiltration.

The sealing layer needs to ideally achieve a saturated hydraulic conductivity of less than $10^{-8} \mathrm{~m} / \mathrm{s}$, so that in its usual unsaturated state its hydraulic conductivity will be less than $10^{-10}$ to $10^{-9} \mathrm{~m} / \mathrm{s}$ (less than 3 to $30 \mathrm{~mm} /$ year). In the absence of suitable or sufficient clayey soils, the sealing layer may be formed by extending the heavy trafficking by loaded haul trucks over the entire top surface of the dump. The cover should cycle annually between wet and dry states without a net wetting up (which would lead to net percolation) or drying out (which would cause vegetation die-back and subsequent rainfall-induced erosion). In Australia's generally arid to semi-arid climate, a eucalypt tree cover represents the only sustainable means of achieving the required evapotranspiration rates from a store and release cover in the long-term. Since the rocky mulch layer is loose, granular, and deep, tree roots are unlikely to penetrate the sealing layer and cause the development of preferred seepage pathways into the underlying waste rock. 


\subsection{Performance of covers on waste rock dumps}

The performance of covers on waste rock dumps is reported in Williams (2008). For relatively young covers in wet climates, or subjected to particularly wet years (greater than about $450 \mathrm{~mm}$ rainfall), both rainfallshedding and store and release covers show relatively high net percolation as a percentage of average annual rainfall (up to $61 \%$ for rainfall-shedding covers and up to $13 \%$ for store and release covers). The highest net percolation corresponds to rainfall-shedding covers on slopes that do not incorporate a compacted sealing layer.

In dry climates, relatively young rainfall-shedding covers show net percolation of about $5 \%$ of average annual rainfall, with a general exponential deterioration with time due to the loss of cover integrity, particularly after 10 years. In dry climates, store and release covers incorporating a sealing layer show good performance up to at least 10 years (the maximum age reported), with net percolation of generally less than $2 \%$ of average annual rainfall.

\section{$5 \quad$ Guidelines for improved management of waste rock}

The management of waste rock and the closure of a surface waste rock dump are about much more than retrospectively constructing a cover on the top of the dump. Guidelines for the improved management of waste rock to achieve completion and to mimimise the potential for AMD are presented in the following sections.

\subsection{Summary guidelines}

The suggested guidelines are summarised in the following:

1. Understand the climatic setting in which the mine is located, including its potential variability, and the impact this will have on the management of waste rock.

2. Undertake waste rock characterisation:

a. Through geochemical characterisation, identify the volumes and distribution of reactive PAF, benign NAF and alkaline waste rock, and other materials.

b. Stockpile materials beneficial for operations and rehabilitation, such as topsoil and benign, durable rip rap.

c. Through physical characterisation, determine the bearing capacity, deformation and hydraulic conductivity of the waste rock types.

3. Water management, including:

a. Active separation of clean from mine-affected waters.

b. Active collection of mine-affected water during operations.

c. Passive management of water post-closure, to minimise erosion, and sediment and contaminant transport to the environment.

4. Schedule waste rock mining and the design and stage-construct surface waste rock dumps to encapsulate PAF, including:

a. Placement of a base layer of benign or alkaline waste rock to drain clean base flowthrough from upstream of the dump.

b. Construction of encapsulation cell(s), with a wide side encapsulation of NAF or alkaline waste rock so that PAF waste rock will never be beneath slopes or intermediate benches (requiring the PAF toe to be greater than 0.5 times the height of the last lift in from the final dump crest, both during operations and post-closure after any slope flattening; see Figure 12), and allowing flowthrough of clean water beneath each PAF cell. 
c. Placement of PAF waste rock in cells with a sloping top surface to shed rainfall runoff during construction.

d. Covering of exposed PAF waste rock by benign or alkaline waste rock and its compaction by loaded haul trucks prior to each wet season to limit rainfall infiltration (and reduce oxygen ingress), in much the same way as landfill is progressively covered.

5. Construct the final surface waste rock dump landform in plan and in section to mimic surrounding natural landforms and surface textures:

a. Incorporate ridges and bold rock-lined gullies, for the sustainable control of surface water and for aesthetics (uniform slopes of any angle 'look' unnatural).

b. Avoid excessive flattening of the outer slopes, which buries and crushes coarse-grained material (increasing runoff and decreasing erosion resistance; see Figure 13(a)), and enlarges the catchment for a given slope height, further increasing runoff; rather create 'natural' convexo-concave slopes by, for example, retaining upper lift(s) at the angle of repose, and pushing out only the lower lift (see Figure 13(b)).

c. Place erosion-resistant, durable NAF or alkaline waste rock on the outer slopes.

d. Construct a low net percolation top cover, such as a store and release cover; incorporating a drainage layer, or using a robust rainfall-shedding cover, in wet climates.

Further details are provided in the following sections.

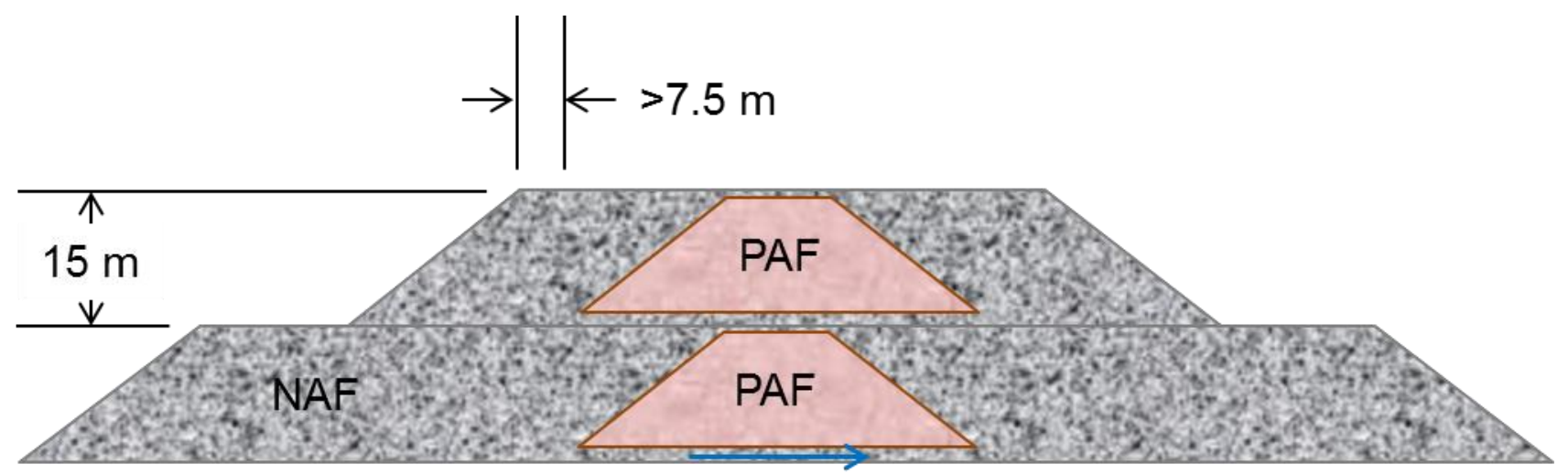

Figure 12 Construction of PAF waste rock encapsulation cells

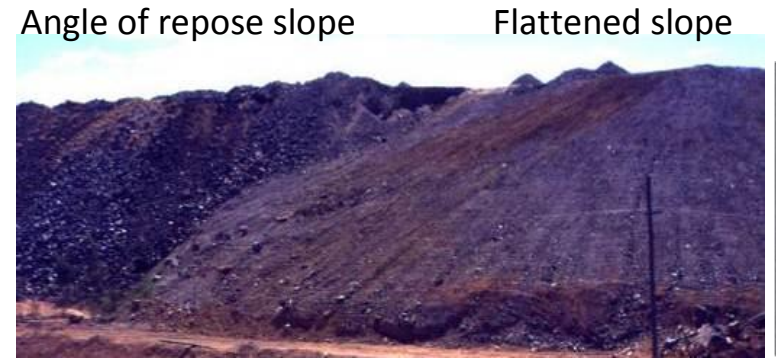

(a)

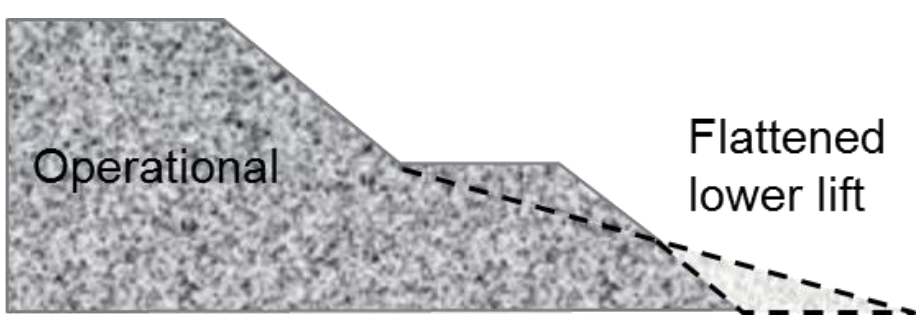

(b)

Figure 13 Guidelines for slope reprofiling: (a) avoid excessive slope flattening, and (b) create convexo-concave profiles

\subsection{Climatic setting}

The climatic setting is key to the performance of surface waste rock dumps, both during mining operations and post-closure. In particular, the wetter the climate, the more rapidly will the dump wet-up. Surface 
waste rock dumps are sponge-like, allowing of the order of $50 \%$ of incident rainfall to infiltrate, potentially collecting and flushing any oxidation products, and leading to the eventual generation of AMD. For the average annual rainfall for Australia of $600 \mathrm{~mm}$, this sponge effect generates an effective 1.5 fold increase in excess moisture compared to natural recharge rates. It is also essential to divert clean runoff to separate it from any surface expression of seepage from the waste rock dumps.

If the dump is left open to oxygen ingress and rainfall infiltration for say 20 years, and if an impermeable cover is placed at that time, the water stored in the dump will drain down over a period of a further 20 years or more. Just as wetting up will increase exponentially with time, drain down will decrease exponentially with time. In reality, an impermeable cover will not be possible, and the drain down will eventually reach the net percolation rate through any cover.

\subsection{Waste rock characterisation}

The waste rock must first be characterised geochemically to identify the volumes and distribution of reactive PAF, benign NAF and alkaline waste rock, and to allow the planning of the effective progressive encapsulation of the PAF waste rock by NAF or alkaline waste rock. The majority of the benign NAF waste rock will typically come from shallow depth above the groundwater table in the early stages of an open pit, unless the pit is developed by a series of deep cut-backs. As the open pit develops, the proportion of reactive PAF waste rock is likely to rise, as the pit extends below the water table. Waste rock that might generate neutral metalliferous or saline drainage would also need to be identified.

Materials beneficial for operations and rehabilitation, such as topsoil and benign, durable rip rap, should be separated and stockpiled for future use. Where progressive rehabilitation of surface waste rock dumps is possible, the beneficial materials can be utilised directly as they are excavated. Physical characterisation of the waste rock and beneficial material streams will enable their bearing capacity, deformation and hydraulic conductivity to be determined. In addition, studies will be required to determine the potential of different materials to support the establishment and sustainability of eventual revegetation.

\subsection{Selective placement and encapsulation of PAF waste rock}

A layer of benign NAF or alkaline waste rock should be placed at the base of waste rock dumps and intermediate lifts, to handle the flowthrough of clean water from catchments and slopes upstream of the dump. The inclusion of alkaline waste rock has the added benefit of adding alkalinity to neutralise potential AMD from any PAF waste rock stored above the base layer.

The proportion of reactive PAF waste rock compared with benign NAF waste rock, and the scheduling of the two waste rock streams, will dictate the balance between dump height, area and final side slope angle required to fully encapsulate the PAF waste rock beneath the flat top surface of the dump, throughout the mine life. Haulage costs will also influence the dump width and height, since the cost of vertical haulage is about four times that of horizontal haulage, and dozing costs will influence the final side slope angle adopted and the selection of post-mining land use.

PAF waste rock should be placed in cells on a base of NAF or alkaline waste rock, and surrounded with a wide encapsulation of NAF or alkaline waste rock, with no PAF waste rock located beneath dump slopes or intermediate benches. The top surface of each PAF waste rock cell should be sloped to shed rainfall runoff during construction, and covered by benign or alkaline waste rock compacted by loaded haul trucks prior to each wet season to limit rainfall infiltration and reduce oxygen ingress.

\subsection{Final waste rock dump landform}

The final surface waste rock dump landform should, where possible, mimic surrounding natural landforms and surface textures, incorporating ridges and bold rock-lined gullies, and avoiding excessive flattening of the outer slopes, to form 'natural' and sustainable convexo-concave slope profiles. Erosion-resistant, durable NAF or alkaline waste rock should be placed on the outer slopes of the waste rock dumps in dry 
climates that do not support an adequate vegetation cover to limit erosion. A slope comprising durable rock will likely be geotechnically, as well as erosionally stable, at its angle of repose. Fine-grained material can be incorporated to promote moisture retention and revegetation. On the top surface of the waste rock dump, a low net percolation cover should be constructed. This could involve a store and release cover, incorporating a drainage layer in wet climates, or a robust rainfall-shedding cover in wet climates.

\section{Conclusions}

The conventional storage of waste rock in surface dumps that are left uncovered for the life of the mine causes a wetting-up of the waste rock and an eventual breakthrough of rainfall infiltration to the base of the dump, accompanied by AMD generated by the inevitable oxidation of any reactive waste rock present within the dump. Any seepage from the toe of the dump or percolation into the foundation will continue for many years, even after an effective low percolation cover, such as a store and release cover, has been constructed. Reactive waste rock should therefore be placed in cells encapsulated at the base and sides by benign or alkaline waste rock, with the flat top surface of each cell covered prior to each wet season to limit wetting-up. A low percolation cover should be constructed on the final top surface of the dump.

\section{Acknowledgement}

This paper draws on research over a number of years, involving a number of research students, site personnel including Nick Currey then at Kidston and Glen, and colleagues including Professor Ward Wilson now of the University of Alberta, Canada.

\section{References}

Beekmann, H.E., Gieske, A. and Selaolo, E.T. (1996) GRES: Groundwater recharge studies in Botswana 1987-1996, Botswana Journal of Earth Sciences, III, pp. 1-17.

Cook, P.G., Leaney, F.W. and Miles, M. (2004) Groundwater recharge in the North-East Mallee Region, South Australia, CSIRO Technical Report, No. 25/05, July 2004, 80 p.

Cox, R. and McKay, A. (2003) The Queensland Great Artesian Basin water resource plan, Proceedings of Water in Mining 2003, 13-15 October 2003, Brisbane, Australia, pp. 177-184.

Fredlund, D.G. and Rahardjo, H. (1993) Soil mechanics for unsaturated soils, John Wiley and Sons, New York.

Fredlund, D.G., Xing, A. and Huang, S. (1994) Predicting the permeability function for unsaturated soils using the soil water characteristic curve, Canadian Geotechnical Journal, Vol. 31, pp. 533-546.

Fredlund, M.D., Fredlund, D.G. and Wilson, G.W. (1997) Prediction of the soil water characteristic curve from grain size distribution and volume mass properties, Proceedings of Third Brazilian Symposium on Unsaturated Soils, Rio de Janeiro, Brazil, 22-25 April 1997, $12 \mathrm{p}$.

Rohde, T.K. and Williams, D.J. (2009) Early hydrological monitoring of Cadia's instrumented trial waste rock dump, in Proceedings of Securing the Future and Eighth International Conference on Acid Mine Drainage, Skelleftea, Sweden, 22-26 June 2009, $12 \mathrm{p}$.

Williams, D.J. (2006) The case for revolutionary change to mine waste disposal and rehabilitation, Proceedings of Second International Seminar on Strategic versus Tactical Approaches to Mining, Perth, Australia, 8-10 March 2006, Australian Centre for Geomechanics, Perth, $19 \mathrm{p}$.

Williams, D.J. (2007) Strategies for reducing seepage from surface tailings storage facilities during operation and post-closure, in Proceedings Second International Seminar on Mine Closure (Mine Closure 2007), A.B. Fourie, M. Tibbett and J.V. Wiertz (eds), 16-19 October 2007, Santiago, Chile, Australian Centre for Geomechanics, Perth, pp. 533-542.

Williams, D.J. (2008) The influence of climate on seepage from mine waste storages during deposition and post-closure, in Proceedings Third International Seminar on Mine Closure (Mine Closure 2008), A.B. Fourie, M. Tibbett, I.M. Weiersbye and P. Dye (eds), 14-17 October 2008, Johannesburg, South Africa, Australian Centre for Geomechanics, Perth, pp. 461-473.

Williams, D.J. and Rohde, T.K. (2008) Waste rock dump rainfall infiltration and base seepage at Cadia, in Proceedings of Sixth Australian Workshop on Acid and Metalliferous Drainage, Burnie, Australia, 15-18 April 2008, ACMER, Brisbane, pp. 151-162.

Williams, D.J., Stolberg, D.J. and Currey, N.A. (2006) Long-term performance of Kidston's store/release cover system over potentially acid forming waste rock dumps, in Proceedings of Seventh International Conference on Acid Rock Drainage, St Louis, Missouri, USA, 26-30 March 2006, pp. 2,385-2,396.

Williams, D.J., Wilson, G.W. and Currey, N.A. (1997) A cover system for a potentially acid forming waste rock dump in a dry climate, Proceedings of Fourth International Conference on Tailings and Mine Waste, Fort Collins, Colorado, 13-17 January 1997, pp. 231-235. 